\title{
El convenio arbitral en el Decreto Legislativo 1071
}

\author{
Luciano Barchi Velaochaga
}

\section{Antecedentes: la cláusula compromisoria y el compromiso arbitral en el Código Civil}

El Código Civil peruano regulaba en el artículo 1906 y siguientes la "cláusula compromisoria", y en el artículo 1909 y siguientes el "compromiso arbitral". Estas normas fueron derogadas por el Decreto Ley 25935.

Conforme al artículo 1906:

Las partes pueden obligarse mediante un pacto principal o una estipulación accesoria, a celebrar en el futuro un compromiso arbitral. En tal caso, no se requiere la designación de los árbitros. Es obligatorio fijar la extensión de la materia a que habrá de referirse el arbitraje. No es de aplicación a la cláusula compromisoria lo dispuesto en el artículo 1416.

La "cláusula compromisoria" era un contrato preparatorio ("preliminar", se decía en el artículo 1907) -concretamente, un compromiso de contratar $^{1}-$, en virtud del cual los otorgantes se obligaban a celebrar en

1 El compromiso de contratar está regulado en el Código Civil, en los artículos 1414 y siguientes. 
el futuro un "compromiso arbitral" en el caso de que surgiera una controversia. Este contrato preparatorio podía adoptar la forma de una cláusula incluida en un contrato y en tal sentido era una "cláusula compromisoria" (estipulación accesoria), o la forma de un acuerdo independiente (pacto principal), en cuyo caso la denominación "cláusula compromisoria" era inexacta (Cárdenas Quirós 2000: 637).

Lohmann Luca de Tena señalaba: "la cláusula compromisoria es aquel convenio por el cual las partes se obligan a someter a arbitraje todas o algunas discrepancias que en el futuro se susciten entre ellas derivadas de una relación jurídica concreta, y que puedan ser objeto de solución arbitral" (1987: 79). Para este autor, el enunciado del artículo 1906 del Código Civil tenía gran proximidad con el del artículo 1414, el que establecía: "Por el compromiso de contratar las partes se obligan a celebrar en el futuro un contrato definitivo".

No obstante, el autor citado consideraba que no existía equivalencia jurídica entre el compromiso de contratar y la "cláusula compromisoria": "[...] a juzgar por las características que la ley atribuye o reclama para el contrato preparatorio, el convenio preliminar de arbitraje no podría considerarse stricto sensu como uno de los preparatorios. La compromisoria está exonerada de las exigencias que la ley impone a los preparatorios" (1987: 82). Luego, Lohmann Luca de Tena añadía:

Mientras el primero [el contrato preparatorio] tiene por propósito que las partes se obliguen a celebrar en el futuro un contrato definitivo, cuyas bases se sientan, pero que hará nacer en su momento una nueva y distinta relación jurídica, el segundo [el preliminar de arbitraje] tiene por cometido vincular a la situación pre-arbitral, excluyente desde ya de la jurisdicción ordinaria. Esta situación pre-arbitral, ya envuelve e involucra a las partes del arbitraje, trazando el círculo maestro bajo cuyas directrices deben conducirse y quedando sólo por concretar cuestiones complementarias que no modifican lo esencial del vínculo. Esto es, por cierto, mucho más que obligarse a celebrar un futuro contrato y nada tiene que ver con la fijación de un contenido básico del contrato definitivo, que no se exige en el preliminar de arbitraje (1987: 82).

Para Lohmann Luca de Tena, el "preliminar de arbitraje" no era verdaderamente un contrato: 
Este convenio es un acuerdo, por descontado, y crea ciertas obligaciones como se acaba de decir líneas más arriba, pero no son obligaciones de carácter patrimonial, ni es el pacto preliminar un acto conciliador de intereses distintos, como es lo propio del contrato. Antes bien, el convenio compromisorio estipula un interés o finalidad común, consistente precisamente en la voluntad arbitral de las partes. Por lo demás, el facere debido por las prestaciones de conducta materia de la obligación del convenio compromisorio, ni siquiera puede dar lugar - salvo pacto expreso - a indemnización pecuniaria por incumplimiento, cuando no se invoca la intervención judicial que formalice el compromiso arbitral en rebeldía (1987: 83).

Para este autor:

[...] es más seguro calificar al convenio preliminar de arbitraje como un negocio jurídico con ciertas características contractuales. Es decir, no es recomendable imputar auténtico atributo precontractual típico a este convenio preliminar arbitral no solo por la dificultad de identificar con nitidez las señas de lo que es exactamente un pre-contrato, sino porque los alcances del preliminar exceden en mucho la exclusividad de obligarse a celebrar otro contrato (1987: 84).

Al respecto, Cárdenas Quirós decía: “La cláusula compromisoria es un contrato preparatorio, no obstante lo cual, se ha preferido brindarle un tratamiento separado, dadas sus peculiaridades que la distinguen de cualquier otro caso de compromiso de contratar" (1985: 650).

Así, conforme al artículo 1425 del Código Civil: “Los contratos preparatorios son nulos si no se celebran en la misma forma que la ley prescribe para el contrato definitivo bajo sanción de nulidad".

En tal sentido, teniendo en cuenta que el artículo 1910 del Código Civil establecía que el "compromiso arbitral" debía constar por escrito bajo sanción de nulidad, la "cláusula compromisoria" también tenía que constar por escrito (bajo sanción de nulidad).

Pero, por otro lado, el artículo 1415 del Código Civil no resultaba de aplicación a la "cláusula compromisoria". Dicho artículo establece: "El compromiso de contratar debe contener, por lo menos, los elementos esenciales del contrato definitivo".

Esta norma no resultaba de aplicación a la "cláusula compromisoria" porque la controversia que puede dar lugar a la celebración del "com- 
promiso arbitral" no existe en el momento de celebrar la "cláusula compromisoria" (1985: 651).

Finalmente, resulta oportuno recordar que el artículo 1906 del Código Civil establecía: "No es de aplicación a la cláusula compromisoria lo dispuesto en el artículo 1416". En efecto, el artículo 1416 del Código Civil señalaba: ${ }^{2}$ "El plazo del compromiso de contratar será no mayor de un año y cualquier exceso se reducirá a este límite. A falta de plazo convencional rige el máximo fijado por este artículo".

Cárdenas Quirós decía: "Resulta obvio que esta limitación no puede aplicarse a la cláusula compromisoria, puesto que ello haría impracticable la formalización del compromiso, si la divergencia surge transcurrido ese plazo. La figura perdería su atractivo por completo en los contratos cuya vigencia se extendiera más allá del plazo de un año [...] (1985: 652)".

Resulta claro que tanto para Lohmann Luca de Tena como para Cárdenas Quirós no existía plena equiparación entre el compromiso de contratar y la "cláusula compromisoria". No obstante, para Cárdenas Quirós la "cláusula compromisoria" era un contrato, mientras que para Lohmann Luca de Tena no lo era.

Conforme al artículo 1909 del Código Civil: "Por compromiso arbitral dos o más partes convienen que una controversia determinada, materia o no de un juicio, sea resuelta por tercero o terceros a quienes designan y a cuya jurisdicción y decisión de someten expresamente".

Teniendo en cuenta que en virtud de la "cláusula compromisoria" las partes se obligaban a celebrar un "compromiso arbitral", cualquiera de ellas, una vez surgida la controversia, podía exigir a la otra su celebración. Como señalaba Cárdenas Quirós: "Si la controversia no ha nacido, no resulta posible la concertación del compromiso. Si se extinguió en virtud de sentencia u otro acto jurídico, tampoco es factible ello" (1985: 658).

Del artículo 1909 se desprendía: a) que los compromitentes podían ser dos o más partes; b) que el objeto del "compromiso arbitral" era una controversia determinada, la cual debía especificar "todas las circunstancias del conflicto con la mayor precisión y exactitud" (1985:

2 La Ley 27420 modificó posteriormente el artículo 1416, en los siguientes términos: "El plazo del compromiso de contratar debe ser determinado o determinable. Si no se estableciera el plazo, este será de un año". 
658); y c) que la solución de la controversia era atribuida a uno o más terceros.

Asimismo, conforme a lo establecido en el artículo 1910, el "compromiso arbitral" es un contrato ad solemnitatem; es decir, debía constar por escrito, bajo sanción de nulidad.

Pero, para Lohmann Luca de Tena, el "compromiso arbitral" tampoco era un contrato:

Ortodoxamente, creo que la respuesta debe ser la misma, ya que el compromiso arbitral carece por sí o en sí de significación económica directa que distinga su esencia. Es decir, que no necesariamente constituye, modifica, regula ni extingue un derecho patrimonial o, si se prefiere, una relación económica entre las partes distinta de la anterior. Por otro lado, si calificamos los contratos como negocios jurídicos plurilaterales con los que directamente se armonizan intereses divergentes, tampoco es apropiado considerar como tal el compromiso arbitral. Más bien, se supone que este acuerdo descansa en el interés conjunto de voluntades para que un tercero ajeno resuelva un conflicto concreto suscitado por otra relación jurídica precedente (que sí debe tener significancia patrimonial, aunque no imprescindiblemente económica) (1987: 108).

El compromiso de contratar es, de acuerdo con nuestro Código Civil, un contrato preparatorio en virtud del cual las partes se obligan a celebrar en el futuro un determinado contrato, llamado "contrato definitivo".

El compromiso de contratar puede ser unilateral o bilateral. Es unilateral cuando la obligación de concluir el contrato definitivo no es asumida de manera recíproca por ambas partes (que es el caso del bilateral), sino por una sola de las partes frente a la otra, de tal manera que esta última tiene derecho al contrato, pero no tiene la obligación de contratar.

En este sentido, la definición de Bianca resulta más descriptiva, cuando señala: "El contrato preliminar es el contrato mediante el cual una o ambas partes se obligan a la estipulación de un sucesivo contrato, llamado definitivo" (1998: 185). ${ }^{3}$ En efecto, como se desprende de dicha definición, el compromiso de contratar puede ser unilateral o bilateral. Es

3 Ver también Paladini (1992: 345). 
unilateral cuando solo una de las partes es la que se encuentra obligada, dentro de un plazo establecido, a celebrar en el futuro un contrato definitivo y la otra parte tiene el derecho a exigirlo. ${ }^{4}$ Es bilateral cuando ambas partes se encuentran obligadas a celebrar en el futuro un contrato definitivo $\mathrm{y}$, asimismo, ambas partes tienen el derecho de exigírselo a la otra.

Como puede apreciarse, el compromiso de contratar es creador de relaciones obligatorias. Sacco y De Nova sostienen que el compromiso de contratar no solo obliga a prestar el consentimiento para la conclusión del contrato definitivo, sino que obliga a concluirlo, es decir, a hacer todo aquello que es necesario y suficiente para que el contrato definitivo produzca sus efectos (1996: 272-273).

De acuerdo con el artículo 1906 del Código Civil, en virtud de la "cláusula compromisoria" las partes se obligan a celebrar en el futuro un compromiso arbitral, por lo que puede afirmarse que aquella era un compromiso de contratar bilateral, donde ambas partes asumían recíprocamente la obligación de concluir tal "compromiso arbitral".

Si una de las partes requería a la otra para celebrar el compromiso arbitral y esta se negaba a hacerlo, aquella podía valerse del remedio de la ejecución específica y requerir al juez competente para que lo "formalice".

Este sistema no resultó. Al respecto, Cantuarias Salaverry señala: "aun cuando las partes hubieran suscrito un contrato de cláusula compromisoria, cuando la controversia les era conocida, ellas debían otorgar un compromiso arbitral, como requisito necesario para activar la vía arbitral"; y añade:

Lo que sucedía en la generalidad de los casos era que, solicitado el otorgamiento del compromiso arbitral por una de las partes (obviamente, la cumplidora), la otra se negaba ha [sic] suscribirlo. Ante esta situación, ¿qué cabía hacer? Pues nada más y nada menos que acudir al Poder Judicial, para que, luego de un largo proceso, fuera el juez quien en rebeldía otorgara el bendito compromiso arbitral.

Así, "por imposición de este absurdo sistema, las partes terminaban, en la generalidad de los casos, en manos de los jueces. Es decir, termi-

4 En caso de incumplimiento de la obligación de contratar, se recurre al remedio de la ejecución coactiva en forma específica (artículo 1418 del Código Civil). 
naban acudiendo forzosamente donde no querían ir". Y Cantuarias Salaverry concluye: " ¿Cuál era la consecuencia de todo esto? Pues, simplemente, que el arbitraje resultaba siendo un sistema absolutamente inoperante" (2007: 114).

El Decreto Ley 25935, al derogar los artículos referidos a la cláusula compromisoria y al compromiso arbitral, introdujo en el ordenamiento jurídico peruano la noción de "convenio arbitral", y en su artículo 4 señalaba:

Por el convenio arbitral las partes someten al conocimiento y decisión de uno o más árbitros, la solución de las controversias que en el futuro puedan surgir entre ellas como consecuencia de un contrato o de otras relaciones jurídicas identificadas, o las controversias ya existentes y determinadas, sean o no materia de un proceso. $[\ldots]$.

El arbitraje es un instituto que se funda y se rige por la voluntad de las partes, y el acto en el cual tal voluntad se expresa se denomina "convenio arbitral". En tal sentido, el acuerdo arbitral deja de estar dividido en dos actos sucesivos, para representarse en un solo acto.

Posteriormente, la Ley 26572 continúa con la noción de "convenio arbitral", al cual define en su artículo 9: "El convenio arbitral es el acuerdo por el que las partes deciden someter a arbitraje las controversias que hayan surgido o puedan surgir entre ellas respecto de una determinada relación jurídica contractual o no contractual, sean o no materia de un proceso judicial $[\ldots]^{\prime \prime}$.

\section{La definición de convenio arbitral en el Decreto Legislativo $1071^{5}$}

El numeral 1 del artículo 13 del Decreto Legislativo 1071 define al convenio arbitral así: "El convenio arbitral es un acuerdo por el que las partes deciden someter a arbitraje todas las controversias o ciertas controversias que hayan surgido o puedan surgir entre ellas respecto de una determinada relación jurídica contractual o de otra naturaleza".

Como señala Roque Caivano, el arbitraje nace a partir de la voluntad de las partes, "que deciden excluir la jurisdicción judicial, remitiendo

5 Este decreto legislativo derogó la Ley 26572. 
determinadas cuestiones litigiosas a la decisión de particulares" (2008: 107). Esta idea choca con la del "arbitraje obligatorio", es decir, aquel arbitraje "cuyas partes son obligadas a convenir, no por su libre elección y concordada voluntad, sino de fuentes extrañas a la voluntad, como leyes o actos administrativos" (La China 2007: 5).

El riesgo que existe con los llamados arbitrajes obligatorios (La China 2007: 5) es que con la imposición de árbitros pueda, en realidad, estarse creando figuras de jueces especiales, violando lo establecido en el inciso 1 del artículo 139 de la Constitución Política del Perú, con lo que se volvería vana la garantía del libre acceso al juez.

El artículo 40 del Decreto Legislativo 1017, Ley de Contrataciones del Estado, establece que los contratos regulados en dicha norma deben incluir necesariamente, y bajo responsabilidad, entre otras cláusulas, una referida a: "Solución de controversias: Toda controversia surgida durante la etapa de ejecución del contrato deberá resolverse mediante conciliación o arbitraje. En caso que en las bases o el contrato no se incluya la cláusula correspondiente, se entenderá incorporada de pleno derecho la cláusula modelo que establezca el reglamento".

Algunos autores hablan, en este caso, de "arbitraje obligatorio" (Falen Incháustegui 2009: 457 ss.). Kundmüller Caminiti, al respecto, señala: "La 'obligatoriedad' ha sido recogida en el artículo 131 del Reglamento y en el artículo 41, inciso b), de la Ley. El 'arbitraje obligatorio' es una figura atípica desde la perspectiva técnica del arbitraje y desde el derecho comparado. Sin embargo, en nuestro medio existen antecedentes de este tipo de arbitraje". Luego, añade: "La 'obligatoriedad' en mención puede estar debidamente justificada por una serie de circunstancias y razones basadas en nuestra realidad" (1999: 217).

Otros autores discrepan de esta posición. Latorre Boza señala, al respecto:

[...] no se trata de una norma que impone el arbitraje de manera absoluta, sino que nos encontramos ante un cuerpo normativo que ha establecido como obligatorio el que las entidades estatales incorporen en sus contratos cláusulas arbitrales e incluso en ausencia de estas cláusulas dispone que se entenderá incorporado el convenio tipo del Reglamento; pero no es posible sostener que se está imponiendo el arbitraje a los privados, pues estos tienen toda la libertad del mundo para decidir si participan o no de un proceso de selección con la expectativa de contratar con el Estado, conociendo de antema- 
no (en la Ley y en el Reglamento) normas de aplicación erga omnes, las reglas (el artículo 41 de la Ley No. 26850 establece una suerte de cláusulas generales de contratación con el Estado) establecidas para la contratación pública (2008: 288).

Opinamos que este no es el caso del "arbitraje obligatorio". En efecto, la Ley de Contrataciones del Estado contiene las disposiciones y los lineamientos que deben observar las entidades del sector público en los procesos de contrataciones de bienes, servicios u obras. En otras palabras, en materia de contratación, el Estado uniformiza los términos respecto de los cuales las entidades del sector público deben contratar para la adquisición de bienes y servicios. Por tanto, estamos más próximos a un supuesto de contrato por adhesión o de cláusulas generales de contratación, que a un supuesto de "arbitraje obligatorio".

Ahora bien, ¿cuál es la naturaleza jurídica del convenio arbitral? Si tenemos en cuenta el artículo 140 del Código Civil, que señala: "El acto jurídico es la manifestación de voluntad destinada a crear, regular, modificar o extinguir relaciones jurídicas $[\ldots]^{\prime \prime}$, entonces podemos afirmar que el convenio arbitral es un acto jurídico.

Ahora bien, el acto jurídico puede ser unilateral, bilateral o plurilateral. De acuerdo con Vidal Ramírez, "la distinción radica en el número de manifestaciones de voluntad que se requieren para la formación del acto jurídico. Si basta una sola manifestación de voluntad el acto es unilateral, si se requiere de la concurrencia o confluencia de dos manifestaciones el acto es bilateral, y si se requieren de tres o más manifestaciones el acto es plurilateral" (2005: 71).

El convenio arbitral se define como "acuerdo", y este es el encuentro de las manifestaciones o declaraciones de voluntad de las partes; en tal sentido, la noción de "acuerdo" nos lleva a la de acto jurídico bilateral o plurilateral y excluye la del acto jurídico unilateral.

No obstante, la sétima disposición complementaria del Decreto Legislativo 1071 señala: “Mediante estipulación testamentaria puede disponerse el sometimiento a arbitraje de las controversias que puedan surgir entre sucesores, o de ellos con los albaceas, incluyendo las relativas al inventario de la masa hereditaria, su valoración, administración y partición [...]".

En ese sentido, en el "arbitraje testamentario" no estamos frente a un "acuerdo", sino frente a un acto jurídico unilateral, donde la voluntad 
del testador es la que decide someter a arbitraje las controversias que puedan surgir entre los sucesores o entre estos y los albaceas. Por otro lado, en el "arbitraje testamentario" no son aquellos entre quienes surge la controversia los que deciden someterla a arbitraje, sino que esta decisión es la de un tercero: el testador. Por consiguiente, el "arbitraje testamentario" no encaja dentro de la definición del numeral 1 del artículo 13 del Decreto Legislativo 1071 y, por tanto, en este caso, en estricto, no debe hablarse de convenio arbitral.

$\mathrm{Al}$ respecto, Vidal Ramírez señala:

[...] además de configurar un genuino acto jurídico bilateral e intervivos, el convenio arbitral puede generarse de un acto unilateral y mortis causa que lo incorpora al testamento y hace obligatorio el arbitraje entre los causahabientes del testador, o generarse de un acto multilateral que lo incorpora a los estatutos de una persona jurídica y lo hace obligatorio entre sus miembros (2003: 569-570).

Conforme a lo expuesto, el convenio arbitral puede definirse como el acuerdo por el que dos o más partes deciden someter a arbitraje todas las controversias o ciertas controversias que hayan surgido o puedan surgir entre ellas respecto de una determinada relación jurídica contractual o de otra naturaleza.

Ahora bien, cabe preguntarse: de acuerdo con el ordenamiento jurídico peruano, ¿el convenio arbitral es un contrato?

Para Castillo Freyre y Vásquez Kunze, sí lo es:

En el tráfico jurídico y comercial de todos los días, esto es, en la realidad, los arbitrajes se contratan, casi en su absoluta mayoría, en lo que se conoce como cláusula arbitral. Esta cláusula es pues un contrato en toda línea. En este contrato las partes se obligan inequívocamente a sustraerse de la jurisdicción del Estado para someterse a una jurisdicción privada determinada por ellas, con el fin de resolver un hipotético conflicto de intereses que pudiera suscitarse de una relación jurídica existente entre ambas, esto es, casi para todos los efectos de la vida diaria, otro contrato del que el arbitral forma parte (2006: 98).

De acuerdo con De Benito Llopis-Llombart, para la mayoría de la doctrina española "el convenio arbitral es, pues - sin perjuicio de lo dispuesto para el arbitraje testamentario en el art. $10 \mathrm{LA}-$, un auténtico contrato" (2010: 39). 
Para Lorca Navarrete, en cambio, el convenio arbitral es "un negocio jurídico impropio". Este autor afirma: "El convenio arbitral, antes que contrato, es la expresión de la inequívoca voluntad de las partes de construir estructuralmente un negocio jurídico; pero no con las consecuencias propias de un contrato sino impropias de un ámbito funcional, tan alejado del contractualismo, como el procesal. La funcionalidad procesal del arbitraje no se justifica en el contractualismo [...]" (2002: 73).

Ahora bien, más allá de las discusiones que encontramos en la doctrina, nacional o extranjera, respecto a si el convenio arbitral es o no un contrato, lo que debe tenerse en cuenta es que la respuesta dependerá de si la definición de convenio arbitral del Decreto Legislativo 1071 encaja dentro de la definición del artículo 1351 del Código Civil.

Como señala Bernardes de Mello:

[...] el mundo jurídico está formado por los hechos jurídicos y estos, a su vez, son el resultado de la incidencia de la norma jurídica sobre su supuesto de hecho cuando se concretiza en el mundo de los hechos. De esto se concluye que es la norma jurídica la que define el hecho jurídico y, por fuerza de su incidencia, genera el mundo jurídico, posibilitando el nacimiento de relaciones jurídicas con la producción de toda su eficacia [...]" (1986: 37).

El artículo 1351 del Código Civil señala: “El contrato es el acuerdo de dos o más partes para crear, regular, modificar o extinguir una relación jurídica patrimonial". Por otro lado, el artículo 1402 dispone: "El objeto del contrato consiste en crear, regular, modificar o extinguir obligaciones".

Conforme con lo señalado anteriormente, el convenio arbitral es un acuerdo de dos o más partes (acuerdo de voluntades), y hasta aquí hay una coincidencia con la noción de contrato del artículo 1351 del Código Civil. Pero en nuestro ordenamiento jurídico, para que el acto sea un contrato, debe crear una relación jurídica patrimonial; en concreto, debe crear una relación jurídica obligatoria (artículo 1402).

Para De Benito Llopis-Llombart, en España el convenio arbitral es un contrato porque es un negocio jurídico bilateral productor de obligaciones; es decir, para el autor español, el convenio arbitral tiene eficacia obligatoria; esto es, obliga contractualmente a someter las disputas a arbitraje y a cumplir el laudo (2010: 85). Esta posición se sustenta en el artículo 11 de la Ley de Arbitraje de España (Ley 60/2003, de 23 de 
diciembre del 2003), que dispone: "El convenio arbitral obliga a las partes a cumplir lo estipulado e impide a los tribunales conocer de las controversias sometidas a arbitraje, siempre que la parte a quien interese lo invoque mediante declinatoria".

En el Perú, para Soto Coaguila (2011: 155), el convenio arbitral es un contrato y, por lo tanto, crea obligaciones para las partes. Según el autor nacional, una vez celebrado un convenio arbitral, las partes contratantes se obligan a:

- $\quad$ Someter sus controversias a un proceso $\operatorname{arbitral}^{6}$ (obligación con prestación de hacer).

- Cumplir con los mandatos impuestos en el laudo arbitral (obligación con prestación de no hacer).

- No acudir a los tribunales judiciales para resolver sus controversias $^{7}$ (obligación con prestación de no hacer).

De la misma opinión es Bullard González, quien afirma: “[...] el arbitraje es obligatorio porque se trata de un contrato y, por tanto, vincula a las partes que suscriben el convenio" (2011: 203).

En nuestra opinión, si bien las partes del convenio arbitral crean una relación jurídica, no crean una relación obligatoria. Veamos. La relación jurídica designa la vinculación entre dos complejos centros de interés; vale decir, la relación entre dos situaciones jurídicas. La situación jurídica es un centro de imputación de derechos y deberes, atribuidos por el ordenamiento legal, cuya titularidad corresponde a uno o más sujetos de derecho (de ahí la expresión: "situación o posición subjetiva").

Las situaciones jurídicas se clasifican en activas y pasivas. La situación jurídica activa es apta para asegurar al titular la obtención de un resultado favorable, es decir, la satisfacción de un interés; y la pasiva es la que sirve de instrumento para la realización de la situación activa. La relación obligatoria supone la relación entre un derecho de crédito (derecho subjetivo) y una obligación.

La obligación es un deber jurídico particular con contenido patrimonial. La obligación supone la necesidad de realizar la prestación debida. Se trata de un deber jurídico que se concreta en la adopción de un deter-

6 Lo que la doctrina conoce (además de la obligación de cumplir el laudo) como "efecto positivo" del convenio arbitral.

7 Lo que la doctrina conoce como "efecto negativo" del convenio arbitral. 
minado comportamiento que ha de ajustarse a los rasgos descritos en el programa de prestación.

El convenio arbitral "es un acuerdo por el que las partes deciden someter a arbitraje todas las controversias o ciertas controversias que hayan surgido o puedan surgir entre ellas respecto de una determinada relación jurídica contractual o de otra naturaleza". En tal sentido, si una parte decide someter a arbitraje alguna controversia que surja, la otra no tiene, en estricto, una obligación. ${ }^{8}$ En la obligación, el sujeto pasivo debe ejecutar su prestación (conducta) para satisfacer el interés del acreedor, el cual, en caso de lesión de su interés, podrá utilizar los remedios que el ordenamiento jurídico pone a su disposición. En cambio, la sujeción hace referencia a la situación pasiva de un sujeto que soporta un poder ajeno y las consecuentes modificaciones de su propia esfera jurídica, sin que ello dependa o se encuentre vinculado a alguna pretensión a su cargo. Si una de las partes decide someter a arbitraje una controversia, la otra no tiene más que aceptar dicha decisión; el comportamiento del sujeto pasivo es irrelevante e incluso el arbitraje se llevará a cabo en su rebeldía.

Por lo general, la situación pasiva denominada "sujeción" se contrapone a un derecho potestativo. El derecho potestativo atribuye al sujeto el poder de incidir en la esfera subjetiva ajena, sin que este pueda oponerse. En tal sentido, basta la iniciativa de una de las partes del convenio arbitral (como titular de un derecho potestativo) para someter una controversia a arbitraje, y la otra parte no podrá oponerse. ${ }^{9}$

Para Fernández-Ballesteros, el convenio arbitral tiene una finalidad inmediata y otra mediata. La inmediata es excluir de la jurisdicción ordinaria el conocimiento de una determinada controversia, y la finalidad mediata es obtener la resolución de esa controversia con los mismos efectos que una sentencia firme. Para este autor, "producido el convenio arbitral, las partes no tienen obligaciones en sentido propio, ni antes, ni durante el proceso arbitral, ni después de su conclusión". ${ }^{10}$ Esto nos

8 En contra: Vidal Ramírez (2003: 571), para quien el convenio arbitral genera obligaciones para las partes. Este autor sustenta su posición en el artículo 9 de la Ley 26572 (ley derogada), que establecía: “El convenio arbitral obliga a las partes y a sus sucesores [...]" (resaltado nuestro). Del mismo modo, para Castillo Freyre y Vásquez Kunze, en virtud del convenio arbitral, "las partes se obligan inequívocamente a sustraerse de la jurisdicción del Estado para someterse a una jurisdicción privada" (2006: 99).

9 En este sentido: Carleo (1998: 46).

10 Fernández-Ballesteros, citado por De Benito Llopis-Llombart (2010: 82). 
aproxima a los llamados "contratos procesales" de la doctrina germánica (Prozessvertrag), es decir, aquellos contratos cuyo principal efecto se presenta en el ámbito procesal. ${ }^{11}$

En tal sentido, el convenio arbitral produce, por un lado, efectos procesales, y, por otro, efectos sustanciales, creando una relación jurídica que no es una relación obligatoria, sino una relación que tiene como situación jurídica pasiva la sujeción y como situación jurídica activa un derecho potestativo, a la que llamaremos "relación arbitral".

Para De Benito Llopis-Llombart, negar la existencia de una relación obligatoria tiene importantes consecuencias. Así, si una de las partes interpusiera una demanda judicial respecto a una materia sometida a arbitraje, ello no implicaría el incumplimiento de una obligación, por lo que esa parte no estaría sujeta a ninguna consecuencia desfavorable, como pago de daños y perjuicios o condena de costas (2010: 84-85).

La relación arbitral tiene, por lo general, carácter recíproco. Así, si una de las partes interpusiera una demanda judicial respecto a una materia sometida a arbitraje, la otra parte podría deducir la excepción del convenio arbitral, ${ }^{12}$ y de no invocarla en el plazo correspondiente, se entendería que renuncia al arbitraje "solo respecto a las materias demandadas judicialmente". ${ }^{13}$

¿Es válido el pacto compromisorio asimétrico ${ }^{14}$ En virtud de la cláusula compromisoria asimétrica, "al menos uno de los compromitentes se reserva la facultad de optar, al plantearse una de las controversias sometidas a arbitraje, entre acudir al arbitraje o a la jurisdicción estatal, quedando la otra parte vinculada por esa elección" (De Benito LlopisLlombart 2010: 56). En principio, sobre la base del principio de la autonomía de la voluntad, creemos que estas cláusulas son válidas. No obstante, tratándose de convenios arbitrales referidos a relaciones jurídicas contenidas en cláusulas generales de contratación o contratos por adhesión, un pacto compromisorio asimétrico a favor del predisponente sería, en nuestra opinión, una cláusula abusiva o vejatoria.

11 Ver De Benito Llopis-Llombart (2010: 63).

12 Artículo 16 del Decreto Legislativo 1071.

13 Artículo 18 del Decreto Legislativo 1071.

14 También llamada cláusula o pacto compromisorio híbrido, mixto, opcional o unilateral. Ver De Benito Llopis-Llombart (2010: 56). 
Por lo expuesto, opinamos que en el ordenamiento jurídico peruano, dado que el convenio arbitral no crea una relación obligatoria entre las partes, dicho convenio no califica como contrato. ${ }^{15} \mathrm{El}$ convenio arbitral es un negocio jurídico al cual se le aplica la disciplina general de los contratos. ${ }^{16}$

\section{Elementos esenciales del convenio arbitral}

Los elementos esenciales del convenio arbitral son:

a) La voluntad de someterse a arbitraje ${ }^{17}$

El artículo 5 de la Ley de Arbitraje de España, de 1988 (ya derogada), establecía:

El convenio arbitral deberá expresar la voluntad inequívoca de las partes de someter la solución de todas las cuestiones litigiosas o de algunas de estas cuestiones, surgidas o que puedan surgir de relaciones jurídicas determinadas, sean o no contractuales, a la decisión de uno o más árbitros, así como expresar la obligación de cumplir tal decisión (resaltado nuestro).

La norma imponía que la expresión de voluntad fuera "inequívoca". Para Matheus López, en el Perú, "la expresión de la inequívoca voluntad posee una indudable relevancia jurídica como expresión de un acto propio consistente en una declaración de voluntad manifestada en términos concluyentes e inequívocos, reveladora de la actitud de quien desea - a través de esa voluntad - suscribir un convenio arbitral [...]" (2005: 288).

En España, Díez-Picazo, criticando la Ley de Arbitraje española derogada, señala: "Requerir que la expresión de la voluntad sea inequívoca significa excluir cualquier posible interpretación de la voluntad y privar de carácter arbitral a los convenios que no

15 Debe tenerse en cuenta, sin embargo, que el Código Civil es impreciso en este tema; así por ejemplo, el contrato de opción tampoco genera una relación obligatoria entre las partes, pero se considera como un contrato.

16 En este sentido, ver Carleo (1998: 13).

17 Ley 60/2003, del 26 de diciembre del 2003. En el artículo 9 de la Ley de Arbitraje española se señala que el convenio arbitral "deberá expresar la voluntad de las partes" de someter a arbitraje todas o algunas controversias que hayan surgido o puedan surgir respecto de una determinada relación jurídica, contractual o no contractual. 
resulten inequívocamente expresados, lo cual es absurdo" (2004: 102).

Inequívoco supone "que no admite duda o equivocación". ¿Ello podría entenderse - como lo sostiene Díez-Picazo - que queda excluida la posibilidad de interpretación? Creemos que la respuesta es negativa.

Como señala Roppo, la razón de la interpretación - su necesidad - está, antes que nada, en el hecho de que los signos usados por los contratantes (principalmente sus palabras, pronunciadas o escritas) pueden ser oscuros o ambiguos: pueden no expresar algún significado inmediatamente perceptible, o bien exprimir dos o más significados posibles, distintos entre ellos (expresiones polisémicas), hasta el extremo de llegar a la antinomia, cuando una proposición del texto expresa un significado y otra exprime un significado opuesto y, por tanto, incompatible. Pero el contrato debe tener un significado y puede tener solo uno: el significado justo. Encontrar el significado justo del contrato es el fin de la interpretación (Roppo 2001: 465).

La interpretación es siempre necesaria, pues todos los signos, cualquiera que sea el código al que pertenezcan, tienen un área de indeterminación semántica que, tras un significado aparente, puede esconder un diverso y más justo significado. Incluso, cuando se dice que "no hay necesidad de interpretación porque el contrato es claro, y tiene claramente un cierto significado, en realidad - aun si inadvertidamente - se interpreta, pues se elige un significado en lugar de otro" ${ }^{18}$

La interpretación es la operación mediante la cual se le atribuye un significado a los signos que manifiestan la voluntad contractual, entendida como "voluntad común" de una determinada regulación contractual. Como señala Bianca: "La interpretación es la operación que determina el significado jurídicamente relevante del acuerdo contractual" (1998: 377). ${ }^{19}$

Dado que el contrato es un acuerdo - es decir, un recíproco consenso-, el significado del contrato debe responder a aquello que

18 Ver Roppo (2001: 465-466). Ver también, en este sentido, Díez-Picazo (1986: 265) y Fernández Cruz (2003: 746).

19 En este mismo sentido, ver Diener (2002: 467). 
las partes han entendido establecer; por tanto, la interpretación no está dirigida a determinar la voluntad de una y de la otra parte, sino a determinar la voluntad "común" que se traduce en el acuerdo.

En ese sentido, siendo la interpretación siempre necesaria, parece absurdo que el adjetivo inequívoco esté dirigido a excluirla. En nuestra opinión, en la medida en que someter a arbitraje la solución de una determinada controversia, supone una renuncia al derecho de acudir al "juez natural preconstituido por ley", solo una manifestación de voluntad inequívoca y directa consentiría admitir que la decisión de recurrir al arbitraje se funda en una libre elección de las partes.

Las lagunas del convenio arbitral son integradas legalmente o con referencia al reglamento arbitral al que se someta. Así por ejemplo, en caso de que las partes no fijaran el número de árbitros que conformarán el tribunal arbitral, los árbitros, de acuerdo con el artículo 19 del Decreto Legislativo 1071, serán tres. Asimismo, el tribunal arbitral decidirá el fondo de la controversia de acuerdo a derecho (inciso 1 del artículo 57 del Decreto Legislativo 1071), salvo que las partes le hubieran autorizado expresamente para decidir en equidad o en conciencia (inciso 3 del artículo 57 del Decreto Legislativo 1071).

b) La determinación de la relación jurídica contractual "o de otra naturaleza" cuyas controversias serán sometidas a arbitraje

Por lo general, cuando el convenio arbitral adquiere forma de cláusula en un contrato, la relación jurídica cuyas controversias serán resueltas por arbitraje es la originada por dicho contrato. Si quedara indeterminada, el convenio arbitral sería nulo.

¿Qué quiso decir el legislador con la expresión: "relación jurídica de naturaleza distinta a la relación jurídica contractual"? Nos parece que la expresión utilizada en el Decreto Legislativo 1071 no es adecuada.

En efecto, de acuerdo con el artículo 1351 del Código Civil, el contrato es el acuerdo de dos o más partes para crear - cuando no regular-, modificar o extinguir una "relación jurídica patrimonial". En tal sentido, surge la duda respecto a lo que el legislador quiso decir con la expresión: "o de otra naturaleza". ¿Se refería a 
una relación jurídica "no patrimonial"? ¿Se refería a una relación jurídica patrimonial, pero que tiene una fuente distinta del contrato?

Pensamos que resulta más adecuado lo establecido en la Ley de Arbitraje española y en la Ley Modelo de la CNUDMI. En ellas se dice: "respecto a una determinada relación jurídica, contractual o no contractual".

La expresión: "relación jurídica", comprende tanto aquellas que tienen contenido patrimonial como aquellas que no lo tienen $\mathrm{y}$, por otro lado, se refiere a aquellas relaciones jurídicas que tienen fuente contractual como a aquellas que no la tienen. Creemos que, finalmente, esta es la lectura que debe darse al numeral 1 del artículo 13 del Decreto Legislativo 1071.

Debe tenerse en cuenta que el convenio arbitral también puede ser adoptado en el estatuto de una persona jurídica, para resolver las controversias entre la persona jurídica y sus miembros, directivos, administradores, representantes y funcionarios, o las que surjan entre ellos respecto de sus derechos u obligaciones, o las relativas al cumplimiento de los estatutos o la validez de los acuerdos (se habla, entonces, de "arbitraje estatutario": sexta disposición complementaria del Decreto Legislativo 1071). También podría incluirse en los reglamentos internos de las juntas de propietarios.

Asimismo, como acto jurídico, le son exigibles los requisitos de validez establecidos en el artículo 140 del Código Civil, ${ }^{20}$ así, se requiere agente capaz para celebrarlo. Los representantes legales, conforme al artículo 167 del Código Civil, requieren autorización expresa para celebrar un convenio arbitral respecto de los bienes del representado. ${ }^{21}$

El artículo 10 del Decreto Legislativo 1071 señala:

1. Salvo pacto o estipulación en contrario, el gerente general o el administrador equivalente de una persona jurídica está facultado por su solo nombramiento para celebrar convenios arbitrales, representarla en arbitrajes y ejercer todos los derechos y facultades previstos

20 En este mismo sentido: Vidal Ramírez (2003: 572).

21 Ver, además, los artículos 448, 532 y 568 del Código Civil. 
en este Decreto Legislativo, sin restricción alguna, incluso para actos de disposición de derechos sustantivos que se discuten en las actuaciones arbitrales.

2. Salvo pacto o estipulación en contrario, la facultad para celebrar determinados contratos comprende también la facultad para someter a arbitraje cualquier controversia derivada de dichos contratos.

El numeral 2 del artículo citado establece que, salvo pacto en contrario, la facultad para celebrar determinados contratos comprende también la de celebrar convenios arbitrales con el fin de someter a arbitraje las controversias que puedan surgir entre las partes respecto de la relación jurídica que se genere de dichos contratos.

En ese sentido, el representante al que se le otorga la facultad de celebrar determinados contratos no requiere que se le otorgue de manera expresa la facultad de celebrar convenios arbitrales respecto a dichos contratos, sino que dicha facultad se encuentra implícita en el poder otorgado. La facultad para someter a arbitraje las controversias derivadas de dichos contratos tendría que ser excluida expresamente.

Al referirse a "determinados contratos", surge la duda acerca de si un poder con el siguiente tenor: "podrá celebrar toda clase de contratos nominados e innominados" o "negociar, celebrar, suscribir y formalizar todo tipo de contratos y actos jurídicos en general", lleva implícita la facultad de someter a arbitraje las controversias que puedan surgir respecto a cualquiera de los contratos que celebre el representante en virtud de dicho poder. En nuestra opinión, la respuesta es afirmativa.

\section{Extensión del convenio arbitral}

De acuerdo con el numeral 1 del artículo 13 del Decreto Legislativo 1071, las partes pueden someter a arbitraje "todas las controversias" o "ciertas controversias" que hayan surgido o puedan surgir entre ellas respecto de una determinada relación jurídica contractual.

Controversias "que hayan surgido" supone que la controversia existe en el momento de la celebración del convenio arbitral; es decir, se trata de una controversia actual. Controversias "que puedan surgir" supone que la controversia es futura y eventual y, por tanto, no existe en el momento de la celebración del convenio arbitral. 
Por otro lado, al celebrar el convenio arbitral, son las propias partes las que deciden si se someten a arbitraje "todas las controversias" o solo "ciertas controversias" que puedan surgir entre ellas (controversias futuras) respecto a una determinada relación jurídica contractual (aun si esta ya se hubiera extinguido). Así, las propias partes pueden limitar el ámbito de operatividad del convenio arbitral limitando su aplicación solo a ciertas controversias o excluyendo en forma expresa aquellas controversias que, siendo susceptibles de arbitraje, no desean someter a la competencia arbitral.

Que sean ciertas controversias y no todas las controversias, significa que las partes pueden restringir las que serán sometidas al arbitraje; así por ejemplo, podría acordarse que solo lo sean las controversias relativas a la resolución del contrato.

De la lectura de los diversos artículos del Decreto Legislativo 1071, puede advertirse que el legislador ha adoptado el principio favor arbitrati. Así, en caso de duda - porque las partes utilizan en la redacción del convenio expresiones genéricas o más bien vagas para indicar el ámbito de operatividad del mismo, sin especificar su alcance-, el convenio arbitral debe interpretarse en el sentido de que la competencia arbitral se extiende a todas las controversias que derivan de la relación jurídica a la cual dicho convenio se refiere.

$\mathrm{Al}$ respecto, el artículo 808-quarter del Codice di Procedura Civile italiano establece: "En caso de duda, la convención arbitral se interpreta en el sentido de que la competencia arbitral se extiende a todas las controversias que derivan del contrato o de la relación a la que la convención se refiere".

\section{5. Ámbito de aplicación del convenio arbitral en las controversias contractuales}

Un problema que se presenta con frecuencia en los procesos arbitrales relacionados con la contratación estatal se refiere a las obras adicionales ejecutadas sin aprobación previa. Se discute si la entidad se encuentra o no obligada al pago de las obras adicionales que el contratista ejecutó, con base en las normas de enriquecimiento sin causa; ${ }^{22}$ en concreto, se discute si esta pretensión es arbitrable.

22 Ver, por ejemplo, Arrarte Arisnabarreta y Paniagua Guevara (2007: 121 ss.), Campos Medina (2006: 307 ss.) y Wong Abad (2008: 83 ss.). 
Algunos autores sostienen que "la única relación jurídica determinada a la que se refiere el convenio arbitral bajo examen es la derivada del contrato administrativo" (Wong Abad 2008: 97); y añaden: "la referencia a cualquier controversia derivada de la ejecución no puede, desde este punto de vista, más que referirse a la relación jurídica contractual, pues si hubiera querido incluir la relación jurídica de enriquecimiento sin causa -inexistente y absolutamente eventual al momento de pactarse el convenio arbitral-, su mención en el mismo debería ser expresa" (Wong Abad 2008: 98). Para estos autores, siendo el enriquecimiento sin causa una fuente heterónoma de relaciones obligatorias, no está comprendido en el convenio arbitral tipo de los contratos sujetos a la LCAE, ${ }^{23}$ el cual se refiere sólo a la relación obligatoria surgida de dichos contratos.

Otros, en cambio, sostienen que "las controversias sobre enriquecimiento sin causa se encuentran comprendidas en el convenio arbitral previsto por el artículo 53 de la LCAE, por lo que deben ser decididas - de manera excluyente - en un arbitraje, siendo incompetente el órgano jurisdiccional para resolver válidamente al respecto" (Arrarte Arisnabarreta y Paniagua Guevara 2007: 156). Para estos autores, cuando el texto del convenio arbitral tipo de la LCAE se refiere a "Todos los conflictos que se deriven de la ejecución e interpretación del presente contrato $[\ldots]]^{\prime \prime}$, comprende entonces el enriquecimiento sin causa que se produce como consecuencia de la ejecución del contrato.

Por lo expuesto, para determinar el ámbito de aplicación del convenio arbitral en las controversias contractuales, debemos remitirnos a dicho convenio, que bajo la forma de cláusula consta en el contrato celebrado.

Cuando el convenio arbitral señala que las partes someten a arbitraje "Cualquier controversia que pudiera surgir entre ellas" o "Todas las controversias que pudieran surgir entre ellas", no queda duda de que las partes decidieron someter a la competencia arbitral todas las controversias que pudieran surgir entre aquellas respecto de la relación jurídica que las vincula. Solo quedan excluidas aquellas controversias que no son susceptibles de arbitraje.

Pero cabe preguntarse si cuando las partes deciden someter todas las controversias que pudieran surgir entre ellas respecto de la relación

23 Ley de Contrataciones y Adquisiciones del Estado, hoy Decreto Legislativo 1017, Ley de Contrataciones del Estado. 
jurídica que las vincula, también están comprendidas las cuestiones extracontractuales derivadas de la relación contractual existente entre las partes.

Como señala Caramaschi, las cuestiones extracontractuales derivadas de la relación contractual son "las controversias que tienen como objeto las consecuencias resarcitorias por hecho ilícito o por responsabilidad precontractual, o derivadas de actos de competencia desleal, o enriquecimiento sin causa de una parte respecto de la otra" (2007: 56).

Opinamos que si las partes deciden, en el convenio arbitral, someter a arbitraje "todo litigio o controversia, derivados o relacionados con este acto jurídico (resaltado nuestro) [...]", ${ }^{24}$ están comprendiendo las cuestiones extracontractuales derivadas de dicho acto jurídico.

\section{La forma del convenio arbitral}

El artículo 13 del Decreto Legislativo 1071 establece: “2. El convenio arbitral deberá constar por escrito. [...]".

Son actos jurídicos formales aquellos para los cuales la ley o la voluntad imponen una forma determinada, bajo sanción de nulidad. Esto no significa que los actos jurídicos respecto de los cuales ni la ley ni la voluntad imponen una forma determinada, bajo sanción de nulidad, carezcan de forma. Todo acto jurídico tiene una forma, pues si no la tuviera no habría la manifestación de voluntad que es necesaria para que haya un acto jurídico. En ese sentido, los contratos formales son la excepción a los actos jurídicos con libertad de forma.

La forma, en los actos jurídicos formales (actos ad solemnitatem), se convierte en elemento constitutivo del acto jurídico; así, si la manifestación de voluntad no reviste la forma prevista, no hay acto jurídico.

El artículo 144 del Código Civil establece: "Cuando la ley impone una forma y no sanciona con nulidad su inobservancia, constituye sólo un medio de prueba de la existencia del acto".

De acuerdo con lo señalado, la forma prevista para el convenio arbitral en el numeral 1 del artículo 13 Decreto Legislativo 1071 es ad probationem, vale decir, existe para facilitar la prueba. En cambio, el primer párrafo del artículo 10 de la Ley 26572 (Ley de Arbitraje derogada)

24 Así, la Cláusula Modelo de Arbitraje del Centro de Arbitraje de la Cámara de Comercio de Lima. 
establecía: "El convenio arbitral se celebra por escrito, bajo sanción de nulidad $[\ldots] "$.

Por lo tanto, en la Ley de Arbitraje derogada, el convenio arbitral estaba sujeto a una forma ad solemnitatem. Matheus López, sin embargo, tenía una posición distinta; para él, el convenio arbitral en la Ley de Arbitraje derogada "viene caracterizado por su libertad formal [...]"; y añadía "[...] la libertad formal que adopta el convenio arbitral en la Ley General de Arbitraje, supone no solo autonomía en la forma de suscripción de esta, sino que además permite tipificar las distintas formas de arbitraje aceptadas legalmente". No obstante, afirmaba luego: "Cabe además precisar que nuestra Ley General de Arbitraje establece como regla general que la forma que ha de revestir el convenio arbitral sea la escrita, forma la cual viene requerida ad solemnitatem, pues su falta haría el convenio nulo (resaltado nuestro)" (2005: 286).

Para Vidal Ramírez, la Ley de Arbitraje derogada prescribía forma ad solemnitatem, y al respecto precisaba: "En consecuencia, su existencia y contenido no podrá ser probado por otro medio que no sea el documento mismo en el que ha sido extendido" (2003: 573).

De acuerdo con Perales Viscosillas, "el criterio del escrito es prevalente en la legislación sobre arbitraje por el efecto expansivo de la Convención de Nueva York y del artículo 7 de la LMA en su versión original; se discrepa en torno a su conceptuación o definición, acerca de su justificación, así como acerca de su eficacia - si es un requisito ad probationem o ad validitatem -" (2007: 207-208). ${ }^{25}$

Ahora bien, si conforme al Decreto Legislativo 1071 el convenio arbitral está sujeto a forma ad probationem, es decir, podrá adoptar cualquier forma, entonces no se explica el fraseo del artículo 13 del Decreto Legislativo 1071, cuando señala:

$[\ldots]$.

3. Se entenderá que el convenio arbitral es escrito cuando quede constancia de su contenido en cualquier forma, ya sea que el acuerdo de arbitraje o contrato se haya concertado mediante la ejecución de ciertos actos o por cualquier medio.

25 LMA es la Ley Modelo de la CNUDMI sobre arbitraje comercial internacional. El artículo 7 de la LMA dice: "El acuerdo de arbitraje deberá constar por escrito". 
4. Se entenderá que el convenio arbitral consta por escrito cuando se cursa una comunicación electrónica y la información en ella consignada es accesible para su ulterior consulta. Por "comunicación electrónica" se entenderá toda comunicación que las partes hagan por medio de mensajes de datos. Por "mensaje de datos" se entenderá la información generada, enviada, recibida o archivada por medios electrónicos, magnéticos, ópticos o similares, como pudieran ser, entre otros, el intercambio electrónico de datos, el correo electrónico, el telegrama, el télex o el telefax.

5. Se entenderá además que el convenio arbitral es escrito cuando esté consignado en un intercambio de escritos de demanda y contestación en los que la existencia de un acuerdo sea afirmada por una de las partes, sin ser negada por la otra [...] (resaltado nuestro).

En efecto, conforme a la cita anterior, se deberá entender que el convenio arbitral es por escrito aun en aquellos casos donde dicha forma realmente no se utiliza. Incluso, no siendo un acto formal, será posible que las partes manifiesten su voluntad de manera tácita; es decir, que la voluntad se infiera indubitablemente de una actitud o de circunstancias de comportamiento que revelan su existencia (artículo 141 del Código Civil).

En tal sentido, el convenio arbitral puede concluirse per facta concludentia; así, la voluntad de las partes deberá ser deducida, no del sentido literal de las palabras - las cuales no existen - , sino del comportamiento concluyente de las partes. ${ }^{26}$ Debe tenerse en cuenta que la conclusión del contrato a través de comportamientos concluyentes no se admite respecto a los contratos para los que se requiere, ad substantiam, la forma escrita.

Esta ha sido la fórmula ("se entenderá que el acuerdo de arbitraje es escrito") adoptada por los numerales 3, 4 y 5 del artículo 7 de la Ley Modelo de la CNUDMI, de donde la toma el legislador peruano. El numeral 3 del artículo 7 de dicha ley señala: "Se entenderá que el acuerdo de arbitraje es escrito cuando quede constancia de su contenido en cualquier forma, ya sea que el acuerdo de arbitraje o contrato se haya concertado verbalmente, mediante la ejecución de ciertos actos o por cualquier otro medio (resaltado nuestro)".

26 Ver, al respecto, Orestano (2006: 243). 
Como puede apreciarse, incluso cuando el convenio arbitral se hubiera concertado verbalmente se entenderá que es escrito, siempre que quede constancia de su contenido en cualquier forma. Como bien señala Perales Viscosillas respecto a este numeral:

El concepto de escrito, sin duda alguna, aparece en este apartado tan deformado que no se reconoce como tal. En este punto es en el que la Ley Modelo puede criticarse no tanto por la solución que se adopta - la "parcial" consagración del principio de libertad de forma-, como por la manera en que se realiza: la distorsión del concepto escrito. Se opta por una solución contra natura. Contra la naturaleza de las cosas. El escrito ya sea en su forma más tradicional como en la evolucionada que ampara a la forma electrónica, no puede equipararse con la forma oral, los actos de ejecución o el silencio o la inacción. Todos ellos no pueden entrar dentro del concepto de escrito (2007: 213).

Por otro lado, debe recordarse que la forma escrita no postula la unidad del documento; así, el convenio arbitral puede resultar del intercambio de correspondencia. En este sentido, Bianca señala: "El contrato es estipulado por escrito cuando el consenso es manifestado en uno o más documentos suscritos por las partes. Las declaraciones pueden ser dadas en tiempos separados y con documentos distintos, como en la hipótesis de contrato formado mediante el intercambio epistolar de las declaraciones" (1998: 294). Por tanto, era innecesario señalar, como lo hacía la Ley de Arbitraje derogada, que "Se entenderá que el convenio arbitral es escrito cuando esté consignado en un único documento firmado por las partes o en un intercambio de cartas, cables, télexes, que dejen constancia documental del acuerdo [...] (resaltado nuestro)".

Entendemos que el legislador ha tenido en cuenta la Convención de Nueva York de 1958, de Reconocimiento y Ejecución de Sentencias Arbitrales Extranjeras. En el numeral 1 del artículo II de dicha convención se señala: "Cada uno de los Estados contratantes reconocerá el acuerdo por escrito conforme al cual las partes se obliguen a someter a arbitraje todas las diferencias o ciertas diferencias que hayan surgido o puedan surgir entre ellas respecto a una determinada relación jurídica, contractual o no contractual, concerniente a un asunto que pueda ser resuelto por arbitraje (resaltado nuestro)".

De acuerdo con González de Cossío: “Los trabajos preparatorios de la Convención de Nueva York revelan que existieron dos motivos detrás 
de dicha decisión: (a) asegurarse que las partes estén conscientes de estar consintiendo al arbitraje; y (b) definir qué constituye un acuerdo escrito" (2008).

La Convención de Nueva York establece el deber de los Estados contratantes de reconocer el convenio arbitral ${ }^{27}$ que conste por escrito; de ahí la preocupación del legislador peruano de considerar que el convenio arbitral consta por escrito aun en casos donde, en estricto, las partes no han utilizado dicha forma para manifestar la voluntad.

$\mathrm{Al}$ respecto, Perales Viscosillas señala - comentando la Ley Modelo de la CNUDMI-:

El problema reside en el deseo del Grupo de Trabajo de separarse del concepto escrito del CNY, pero al mismo tiempo la necesidad de superar su estricto lenguaje y sobre todo interpretación práctica. De ahí la solución artificial que se adopta enmascarando a otras posibles formas de perfección del convenio arbitral o del contrato bajo el concepto de escrito (2007: 213).

El numeral 3 del artículo 9 de la Ley de Arbitraje española establece: "El convenio arbitral deberá constar por escrito, en un documento firmado por las partes [...] (resaltado nuestro)".

Bianca afirma que "por escritura privada o acto escrito se entiende el documento firmado por el autor o por los autores del acto. Por regla no es necesaria la autografía de la declaración, que puede ser escrita por un tercero o a máquina. Lo que importa es, en cambio, que sea autógrafa la firma con la cual el sujeto suscribe el texto"; y luego añade: "La suscripción consiste en la aplicación de la firma autógrafa [...]" (1998: 293). ${ }^{28}$ Como afirma Roppo: "El significado de la firma es la apropiación del texto, la afirmación que ello corresponde a la voluntad contractual de la parte" (2001: 229).

El Decreto Legislativo 1071 no se refiere a la firma; por tanto, el documento que contiene el convenio arbitral puede o no estar firmado por las partes. En tal sentido, la apropiación del texto no requiere necesaria-

27 Numeral 2 del artículo II de la Convención de Nueva York: “La expresión 'acuerdo por escrito' denotará una cláusula compromisoria incluida en un contrato o un compromiso, firmados por las partes o contenidos en un canje de cartas o telegramas".

28 Debe tenerse en cuenta que la falta de suscripción del documento puede ser suplida cuando la parte que no ha firmado se vale del documento. 
mente de la firma; así por ejemplo, podría derivarse del comportamiento de las partes no signatarias.

\section{El convenio arbitral como "cláusula autosuficiente"}

El artículo 13 del Decreto Legislativo 1071 señala: “2. El convenio arbitral deberá constar por escrito. Podrá adoptar la forma de una cláusula incluida en un contrato o la forma de un acuerdo independiente [...] (resaltado nuestro)".

El convenio arbitral podrá adoptar la "forma" de una cláusula incluida en un contrato o la forma de un acuerdo independiente.

Como explica Roppo: "El texto contractual es un conjunto de proposiciones, que expresan cláusulas"; y añade: "La cláusula es la unidad elemental del texto ( $\mathrm{y}$, por tanto, de la regulación) contractual: es una disposición homogénea, con la cual las partes regulan un determinado aspecto de su relación [...]" (2001: 458). ${ }^{29}$

Capobianco habla de "cláusulas autosuficientes" o "cláusulas contrato" o "cláusulas negocio", para referirse a aquellas cláusulas que sobreviven al contrato, siendo susceptibles de vivir un vida autónoma fuera de aquel (2006: 239). Este es precisamente el caso del convenio arbitral bajo la "forma" de cláusula, donde sus requisitos de validez y eficacia se verifican de una manera autónoma respecto a aquellos requeridos para el contrato, y la eventual nulidad de este no se extiende al convenio arbitral.

El convenio arbitral es, pues, un acuerdo dotado de autonomía e individualidad respecto al contrato, y, en tal sentido, el acuerdo puede estar incluido en una cláusula de dicho contrato o puede estar incluido en un documento independiente (convención sucesiva autónoma).

El convenio arbitral bajo forma de cláusula es independiente del contrato en el cual se incluye, de tal manera que la discusión sobre la nulidad del contrato puede ser sometida a arbitraje. Del mismo modo, no existe "conexidad" entre el "convenio arbitral independiente" y el contrato del cual surge la relación jurídica respecto de la cual se resolverá la controversia; por tanto, la discusión sobre la nulidad del contrato puede ser sometida a arbitraje. Como señala De Benito Llopis-Llombart: "[...] una de las notas características de todo pacto compromisorio

29 En el mismo sentido, ver Capobianco (2006: 228). 
es su autonomía o separabilidad: la nulidad del contrato principal no se extiende automáticamente a la cláusula arbitral" (2010: 48).

En ese sentido, el numeral 2 del artículo 41 del Decreto Legislativo 1071 establece:

El convenio arbitral que forme parte de un contrato se considerará como un acuerdo independiente de las demás estipulaciones del mismo. La inexistencia, nulidad, anulabilidad, invalidez o ineficacia de un contrato que contenga un convenio arbitral, no implica necesariamente la inexistencia, nulidad, anulabilidad, invalidez o ineficacia de este. En consecuencia, el tribunal arbitral podrá decidir sobre la controversia sometida a su conocimiento, la que podrá versar, incluso, sobre la inexistencia, nulidad, anulabilidad, invalidez o ineficacia del contrato que contiene el convenio arbitral [...].

Para De Benito Llopis-Llombart, el término autonomía del convenio arbitral es un término ambiguo. Según el autor español, para referirse a la autonomía material, respecto al contrato principal, es preferible el empleo del término separabilidad. ${ }^{30} \mathrm{Al}$ estudiar la relación entre el convenio arbitral y el contrato que lo contiene, la palabra autonomía conduce a pensar que se trata de dos realidades independientes, y lo que le sucede a una no afecta a la otra (2010: 49-50). La clave de la separabilidad se halla en el carácter accesorio de la cláusula arbitral. Esta no se ve afectada, en principio, porque es entonces cuando cumple su función, inherentemente accesoria.

El principio de separabilidad, para De Benito Llopis-Llombart, no significa que el convenio arbitral sea un contrato autosuficiente, pues ello llevaría a la dificultad de explicar los casos de sucesión singular (ejemplo: cesión de créditos) o sucesión universal (ejemplo: fusión de sociedades):

[...] si el pacto compromisorio fuera completamente autosuficiente, no podría, en puridad, ser transmitido automáticamente. Por el contrario, la separabilidad, entendida correctamente como una consecuencia de la accesoriedad de la cláusula, explica de forma natural por qué en esos casos el pacto compromisorio permanece inseparable, como lo que es: una más de las estipulaciones del contrato como unidad negocial (2010: 55).

30 En el derecho americano se habla del principle of separability (Bennett 2002: 60). 
En nuestra opinión, atribuirle al convenio arbitral que adopta la "forma" de cláusula una relación de accesoriedad con el contrato que lo contiene, no permite explicar por qué, en caso de nulidad del contrato principal, lo accesorio (el convenio arbitral) no sigue la misma suerte. Por ello, nos ratificamos en considerar al convenio arbitral bajo la "forma" de cláusula como una cláusula autosuficiente. En ese sentido, el convenio arbitral bajo la forma de cláusula se configura como una "cláusula-negocio" y no como una "cláusula parte".

La consecuencia más relevante que se desprende del principio de autonomía del convenio arbitral respecto al contrato es que los árbitros son competentes para decidir sobre la controversia que verse sobre la inexistencia, nulidad, anulabilidad, invalidez o ineficacia del contrato que contiene el convenio arbitral.

Del mismo modo, la validez del convenio arbitral no se ve afectada por los eventuales vicios del contrato al cual accede; salvo, obviamente, la hipótesis por la cual dichos vicios sean autónomamente relevantes también para el propio convenio arbitral.

\section{Las relaciones jurídicas estándares}

El artículo 15 del Decreto Legislativo 1071 señala:

1. En el arbitraje nacional los convenios arbitrales referidos a relaciones jurídicas contenidas en cláusulas generales de contratación o contratos por adhesión serán exigibles solo si dichos convenios han sido conocidos, o han podido ser conocidos por quien no los redactó, usando una diligencia ordinaria.

2. Se presume, sin admitir prueba en contrario, que el convenio arbitral ha sido conocido en los siguientes supuestos:

a) Si está incluido en las condiciones generales que se encuentran en el cuerpo del contrato principal y este último es por escrito y está firmado por las partes.

b) Si está incluido en las condiciones generales que se encuentran reproducidas en el reverso del documento principal, y se hace referencia al arbitraje en el cuerpo del contrato principal y este último es por escrito y está firmado por las partes.

c) Si se encuentra incluido en condiciones estándares separadas del documento principal, y se hace referencia al arbitraje en el cuerpo 
del contrato principal y este último es por escrito y está firmado por las partes.

\section{Como bien advierte Roppo:}

Los contratos, principal instrumento de los intercambios y de la circulación de la riqueza, son un factor que constituye y define el mercado, entendido como el lugar donde se intercambian bienes y servicios económicos. La regulación de los contratos es por tanto un momento decisivo de la regulación del mercado, especialmente cuando las partes de los contratos son sujetos que tienen un rol de protagonistas institucionales del mismo mercado: las empresas, que ofrecen en el mercado bienes y servicios, y los consumidores, que en el mercado demandan bienes y servicios (2001: 827).

Estamos frente a los contratos de consumo.

La estandarización de los bienes y de los servicios, característica de la actual economía de masa, viene acompañada de la estandarización de los contratos: para la venta de sus bienes o para la prestación de los servicios, la empresa emplea un texto contractual estándar, que es utilizado de manera uniforme en las relaciones que se establecen con todos los clientes (Roppo 2001: 829).

El fenómeno de la estandarización, a su vez, nos lleva a dos fenómenos: el de la predisposición unilateral (cláusulas generales de contratación) y el de la adhesión.

El texto del contrato no es el resultado de las tratativas con el cliente, sino que es preparado, unilateralmente, por la propia empresa. El cliente, si quiere contratar, sólo puede "adherirse" al contrato estándar; es decir, debe aceptarlo sin discutirlo.

La empresa que predispone el texto se llama predisponente; el cliente que se adhiere al texto predispuesto por otro se llama adherente. El adherente es, con frecuencia, un consumidor, pero también puede tratarse de otro empresario (Roppo 2001: 829).

Las cláusulas (o condiciones) generales de contratación (CGC) son las cláusulas que el predisponente utiliza para regular uniformemente sus relaciones contractuales. La noción de CGC se puntualiza en relación con el carácter general de las cláusulas predispuestas. Las CGC están destinadas a regular una serie indefinida de relaciones, contraponiéndose a las cláusulas específicamente elaboradas para relaciones singulares. 
El fenómeno de las CGC se encuentra tan extendido que es difícil que los consumidores puedan acceder a los bienes y servicios sin someterse a la regulación contractual que las empresas predisponen en forma de cláusulas contenidas en módulos o formularios. Esto significa que el contenido de los contratos de consumo es impuesto a los consumidores, los cuales se adhieren a una regulación que no están en grado de negociar y cuyo contenido desconocen con frecuencia.

El artículo 1392 del Código Civil establece: “Las cláusulas generales de contratación son aquellas redactadas previa y unilateralmente por una persona o entidad, en forma general y abstracta, con el objeto de fijar el contenido normativo de una serie indefinida de futuros contratos particulares, con elementos propios de ellos".

La predisposición unilateral genera la posibilidad de establecer cláusulas vejatorias o abusivas por parte del predisponente. Las cláusulas vejatorias son aquellas que agravan la posición del adherente respecto a la disciplina legal del contrato. Así, el artículo 1398 del Código Civil señala:

En los contratos celebrados por adhesión y en las cláusulas generales de contratación no aprobadas administrativamente, no son válidas las estipulaciones que establezcan en favor de quien las ha redactado, exoneraciones o limitaciones de responsabilidad; facultades de suspender la ejecución del contrato, de rescindirlo o de resolverlo; de prohibir a la otra parte el derecho de oponer excepciones o de prorrogar o renovar tácitamente el contrato.

El artículo citado reduce el espacio reservado para la autonomía privada, prohibiendo que se establezcan determinado tipo de cláusulas. Esta norma pretende restablecer el equilibrio entre las partes prohibiendo cláusulas abusivas o vejatorias en los contratos celebrados por adhesión y en las CGC.

El legislador italiano no habla de "cláusulas abusivas", sino de "cláusulas vejatorias", 31 y las define, en el artículo 1469-bis, como "las cláusulas que, a pesar de la buena fe, determinan a cargo del consumidor un

31 En 1996 se modificó el Código Civil italiano, para dar cumplimiento a la Directiva 93/13/CEE del Consejo de 5 de abril de 1993, sobre las cláusulas abusivas en los contratos celebrados con consumidores. De acuerdo con Alpa, “La expresión 'abusiva' es equívoca, extraída por la inexacta versión del texto italiano de la directiva [...]" (2004: 222). 
significativo desequilibrio de los derechos y de las obligaciones derivados del contrato". Esta definición resalta dos criterios de la "vejatoriedad": el significativo desequilibrio ${ }^{32}$ y la contravención a la buena fe objetiva.

Como señala Roppo, "la cláusula crea 'desequilibrio' cuando modifica, dañando al consumidor, las recíprocas posiciones contractuales de las partes como son definidas por el derecho dispositivo (parámetro del nivel de 'equilibrio' de las mismas posiciones). No basta, sin embargo, cualquier desequilibrio, sino un desequilibrio 'significativo' [...]" (2001: 913).

El artículo 1469-ter indica tres criterios que deben aplicarse en el juicio de "vejatoriedad":

1) Debe tenerse en cuenta la naturaleza del bien o del servicio objeto del contrato;

2) Deben tenerse en cuenta las circunstancias existentes en el momento de su conclusión; y

3) Deben tenerse en cuenta las otras cláusulas del mismo contrato o de otro conexo o del cual depende. Al respecto, Roppo afirma: "una cláusula, en sí y por sí fuente de desequilibrio, puede, no obstante, ser considerada no vejatoria si resulta reequilibrada por otra cláusula del mismo contrato o de otro contrato conexo con aquel bajo juicio, que dispongan significativas ventajas para el consumidor" (2001: 914). En tal sentido, la "vejatoriedad" no debe ser observada en una lectura aislada de la cláusula, sino en la lectura de todo el contrato; así, una cláusula podría ser abusiva o vejatoria vista aisladamente, pero no si es vista sistemáticamente. En el mismo sentido, Marques Lima, en Brasil, señala: "La actividad del intérprete para reconocer una cláusula abusiva es crucial y debe concentrarse en la visión dinámica y total del contrato" (2002: 149).

El artículo 1469-bis del Código Civil italiano contiene un elenco de "tipos" de cláusulas; este elenco indica una serie de cláusulas que "se presumen vejatorias, salvo prueba en contrario". Son cláusulas que el

32 De acuerdo con Alpa, “El ‘desequilibrio' presenta dos caracteres: debe ser 'significativo', y debe referirse a derechos y obligaciones de las partes, es decir, tener naturaleza 'jurídica', no económica" (2004: 225). Marques Lima (2002: 148) también se refiere al desequilibrio de derechos y obligaciones entre las partes. 
legislador considera prima facie portadoras de un significativo desequilibrio en desmedro del consumidor y, por tanto, vejatorias. Se clasifican en dos categorías: cláusulas de desbalance o de desequilibrio ${ }^{33}$ y cláusulas de sorpresa. ${ }^{34}$

Dado que se admite la prueba en contrario, puede demostrarse que la cláusula que se presume vejatoria, en concreto no lo es. Esto califica al elenco del artículo 1469-bis como "lista gris", en contraposición al elenco del artículo 1469-quinquies, calificado como "lista negra" en la medida en que las cláusulas de este elenco son calificadas irremediablemente como vejatorias, sin posibilidad de prueba en contrario. En el modelo de la "lista gris" puede considerarse vejatoria, con base en el criterio general, una cláusula ajena al elenco. Esto, sin embargo, en la práctica es poco probable, pues la lista es muy exhaustiva.

Una cláusula puede presentar elementos constitutivos de "vejatoriedad" y aun así no ser vejatoria, por la presencia de elementos impeditivos de la "vejatoriedad", los cuales, según el artículo 1469-ter, son dos:

1) No son vejatorias las cláusulas que reproducen disposiciones legales; es decir, cláusulas que prevén derechos y obligaciones del consumidor ya directamente atribuidas por la ley; ${ }^{35} \mathrm{y}$

2) No son vejatorias las cláusulas o los elementos de cláusula que hayan sido objeto de negociación individual.

La Directiva 93/13/CEE, sobre cláusulas abusivas en los contratos celebrados con consumidores, excluye como cláusulas vejatorias o abusivas aquellas que hayan sido objeto de negociación individual. Esto

33 Cláusulas de desequilibrio son aquellos pactos contractuales que determinan, en daño al consumidor, un significativo desequilibrio de los derechos y de las obligaciones derivadas de la regulación contractual. Ejemplo: son aquellas cláusulas que hacen al profesional (contrapuesto al consumidor) árbitro de la formación o permanencia del vínculo contractual, sin la posibilidad de autónoma decisión resolutoria, que grava al consumidor (Oricchio 2001: 93).

34 Cláusulas de sorpresa son aquellas que tornan la ejecución del contrato de manera muy diferente de aquella que legítimamente el consumidor podía esperar con base en legítimas perspectivas (Oricchio 2001: 93).

35 En este mismo sentido va la Directiva 93/13/CEE: “Considerando que se supone que las disposiciones legales o reglamentarias de los Estados miembros por las que se fijan, directa o indirectamente, las cláusulas de los contratos celebrados con los consumidores no contienen cláusulas abusivas; que, por consiguiente, no resulta necesario someter a las disposiciones de la presente Directiva las cláusulas que reflejan las disposiciones legales o reglamentarias imperativas [...]". 
parte del fundamento según el cual, el fin de tutelar al consumidor se da cuando este está constreñido a adherirse pasivamente a las cláusulas impuestas por el profesional, ${ }^{36}$ pero si hay tratativas, la tutela no se justifica. Corresponde al profesional probar la existencia de negociación. ${ }^{37}$

$\mathrm{Al}$ respecto, Oricchio nos dice: "La nueva normativa comprende [sin exclusión alguna] todos los contratos concluidos entre empresas y consumidores que tienen como objeto la cesión de bienes y el suministro de servicios, cuyas cláusulas no hayan sido objeto de una tratativa entre las partes, sino que hayan sido sustancialmente 'impuestas' por las primeras a los segundos" (2001: 89). Y Alpa señala:

[...] la tratativa puede consistir en la discusión de los contenidos en general de toda la operación económica, y no necesariamente debe haber llevado a una modificación de la cláusula. Se puede considerar realizada la tratativa si resulta que el consumidor haya aceptado cláusulas vejatorias frente a la reducción de la retribución o de otras cargas que, en ausencia de tratativa, habrían sido puestas a su cargo [...] (2004: 223).

En la misma línea, Miquel González, en España, señala: “En el derecho español, no debe perderse de vista que es presupuesto de aplicación de la cláusula general de la buena fe y equilibrio de derechos $\mathrm{y}$ obligaciones que las estipulaciones no hayan sido negociadas individualmente" (2003).

Como ya se dijo, el Código Civil peruano regula las cláusulas vejatorias en el artículo 1398, norma que se aplica tanto a los contratos celebrados por adhesión ${ }^{38}$ como en las CGC no aprobadas administrativamente. ${ }^{39} \mathrm{Si}$ bien es cierto la norma alcanza a los contratos de consumo, ${ }^{40}$

36 La Directiva 93/13/CEE define al profesional como "toda persona física o jurídica que, en las transacciones reguladas por la presente Directiva, actúe dentro del marco de su actividad profesional, ya sea pública o privada". Nuestra Ley de Protección al Consumidor se refiere a "proveedor".

37 En este mismo sentido va la Directiva 93/13/CEE. Las cláusulas señaladas en los numerales 1, 2 y 10 del elenco no son inmunizadas por la negociación conforme al artículo 1469-quinquies, puesto que son reputadas particularmente gravosas para el consumidor.

38 Ver artículo 1390 del Código Civil.

39 Ver artículo 1392 del Código Civil.

40 La Ley de Protección al Consumidor, Decreto Legislativo 716 (TUO: Decreto Supremo 006-2009-PCM), no tiene normas específicas relacionadas con las cláusulas vejatorias. 
no necesariamente debemos identificar al adherente con el consumidor, ni al predisponerte con el proveedor. ${ }^{41}$

De acuerdo con el artículo 1398 del Código Civil, se consideran cláusulas vejatorias aquellas que establezcan, a favor del predisponerte: 1) exoneraciones o limitaciones de responsabilidad;42 2) facultades de suspender la ejecución del contrato, de rescindirlo o de resolverlo; ${ }^{43} 3$ ) de prohibir al adherente oponer excepciones; y 4) prorrogar o renovar tácitamente el contrato. Como bien lo advierte Juan Espinoza: "se plantea como un problema el carácter de la relación de las cláusulas vejatorias contenidas en el artículo 1398; vale decir, si se trata de una disposición de numerus apertus o numerus clausus" (2003: 542).

Para De la Puente y Lavalle, "Dado que el artículo 1398 del Código Civil peruano sigue el mismo sistema que el segundo párrafo del artículo 1341 del Código Civil italiano, o sea que hace una enumeración de casos sin precederlos por una regla general, es plausible entender que tal enumeración es limitativa". Más adelante, este autor añade:

Además, el citado artículo 1398, al establecer que no son válidas determinadas estipulaciones de los contratos por adhesión y en las cláusulas generales de contratación no aprobadas administrativamente, constituye una norma de excepción al principio general contenido en el artículo 1354 sobre la libertad de determinar el contenido del contrato. En estas condiciones, como el artículo IV del Título Preliminar de dicho Código dispone que la ley que establece excepciones o restringe derechos no se aplica por analogía, el elenco de cláusulas vejatorias contenido en el artículo 1398, dado su carácter excepcional, no es susceptible de aplicación analógica (1991: 210).

41 En el mismo sentido: Espinoza Espinoza (2003: 546-547).

42 De acuerdo con De la Puente y Lavalle, "la norma contenida en el artículo 1398 relativa a la exoneración o limitación de responsabilidad se refiere, sin duda, a la derivada de culpa leve, pues de otra manera tal norma sería absolutamente innecesaria" (1991: 204).

43 En este caso, la cláusula solo puede ser considerada abusiva si introduce formas de "receso" o de desistimiento y de resolución diferentes de las consideradas por la ley. Así por ejemplo, la cláusula resolutoria expresa no tiene carácter abusivo, puesto que la facultad resolutoria, como consecuencia del incumplimiento, está prevista en el Código Civil. Ver Cintioli (2003: 417-418); en el mismo sentido: Bianca (1998: 354-355). 
No obstante, luego advierte: "Sin embargo, el hecho de que el citado artículo no sea susceptible de aplicación analógica a cláusulas distintas de las expresadas en él, no excluye su aplicación por interpretación extensiva" (1991: 211).

Arias Schreiber señalaba, al respecto: “En el artículo 1398 se han tenido en cuenta aquellas situaciones que son, a nuestro entender, las más notorias; pero admitimos la posibilidad de que puedan haber otras análogas y que no han sido consideradas en el texto" (1986: 152).

Para Espinoza Espinoza, "en materia de cláusulas vejatorias predispuestas en contratos por adhesión y en cláusulas generales de contratación no aprobadas administrativamente, el Código Civil nos ofrece un elenco ejemplificativo, por cuanto el mismo debe ser interpretado a la luz de los principios de la Constitución" (2003: 543).

En nuestra opinión, el artículo 1398 del Código Civil establece una "lista negra"; en tal sentido, las cláusulas ahí señaladas se consideran abusivas o vejatorias per se. No obstante, si aceptamos que dicho elenco no es taxativo y que podrían considerarse otras cláusulas, entonces creemos que para determinar la "vejatoriedad" de las cláusulas deberían tenerse en cuenta los criterios de "vejatoriedad" recogidos en la Directiva 93/13/CEE y en el artículo 1469-ter del Código Civil italiano.

El Código Civil consideró cláusulas vejatorias o abusivas a la cláusula compromisoria y al compromiso arbitral. Así, el texto original del artículo 1398 establecía:

En los contratos celebrados por adhesión y en las cláusulas generales de contratación no aprobadas administrativamente, no son válidas las estipulaciones que establezcan en favor de quien las ha redactado, exoneraciones o limitaciones de responsabilidad; facultades de suspender la ejecución del contrato, de rescindirlo o de resolverlo; de prohibir a la otra parte el derecho de oponer excepciones o de prorrogar o renovar tácitamente el contrato; y de fijar cláusulas compromisorias y sometimiento a arbitraje [...] (resaltado nuestro).

Posteriormente, con motivo de la promulgación del Código Procesal Civil, se derogó esa parte del artículo citado. No obstante, para Cárdenas Quirós, deberían ser consideradas abusivas las cláusulas que "imponen compulsivamente la utilización del arbitraje o que desvían al adherente de la competencia del juez al cual corresponde considerarlo naturalmente sometido" (2000: 116). 
Ni la Ley de Arbitraje derogada ni el Decreto Legislativo 1071 consideran vejatorias las cláusulas en las que constan convenios arbitrales referidos a relaciones jurídicas contenidas en CGC o contratos por adhesión, siempre que hayan sido conocidas o hayan sido conocibles por la contraparte usando la diligencia ordinaria.

De acuerdo con el Código Civil, cuando se contrata con arreglo a CGC que no han sido aprobadas ex ante por la autoridad administrativa, ellas son eficaces frente al adherente si en el momento de la conclusión del contrato éste las conocía o habría podido conocerlas usando la ordinaria diligencia.

La contraparte debe conocer, en el momento de la conclusión del contrato, las CGC no aprobadas administrativamente; por tanto, se excluye la eficacia de dichas CGC que el consumidor habría tenido la posibilidad de conocer en un tiempo posterior a dicha conclusión, como por ejemplo en aquellos casos que las CGC se encuentran en la factura.

La medida de la diligencia ordinaria debe reportarse a un criterio de normalidad, con referencia a aquello que es normal esperar de la masa de adherentes, en relación con el tipo de operación económica. La aplicación de este criterio excluye que al adherente pueda exigírsele un particular esfuerzo o una particular competencia para conocer las CGC usadas por el predisponente.

El artículo 1397 del Código Civil impone al predisponente la carga de conocibilidad, en el sentido de que debe hacer que las CGC sean conocibles por la contraparte, de la manera más idónea.

Las cláusulas generales de contratación no aprobadas administrativamente se incorporan a la oferta de un contrato particular cuando sean conocidas por la contraparte o haya podido conocerlas usando de una diligencia ordinaria.

Se presume que la contraparte ha conocido las cláusulas generales de contratación cuando han sido puestas en conocimiento del público mediante adecuada publicidad.

La carga de conocibilidad se entiende de dos maneras:

- El conocimiento de la preexistencia de las CGC.

- La inteligibilidad; es decir, las CGC deben ser entendibles. El predisponente debe usar un texto claro; un texto oscuro no cumple este requisito. 
Luego de que el predisponente ha cumplido su carga de conocibilidad, entra en juego la carga de diligencia de la contraparte. El artículo 1397 del Código Civil dice: "[...] o haya podido conocerlas usando de una diligencia ordinaria". Una vez conocida la existencia de las CGC, la contraparte no predisponente debe poner su empeño para conocerlas en su tenor.

El segundo párrafo del artículo 1397 del Código Civil establece una presunción - Arias Schreiber considera que se trata de una presunción iure et de iure; De la Puente, en cambio, que es iuris tantum) - de conocimiento por parte del adherente, cuando las CGC han sido puestas en conocimiento del público "mediante adecuada publicidad". La "adecuada publicidad" debe tener en cuenta, por ejemplo, el público al cual está dirigida.

El Decreto Legislativo 1071 establece la presunción iure et de iure de conocimiento en tres supuestos, los mismos señalados en la anterior ley, pero omite uno que la Ley de Arbitraje derogada sí consideraba: "Si fue puesta en conocimiento del público mediante adecuada publicidad". Esto último sí está considerado en el artículo 1397 del Código Civil; entonces surge la duda de si se aplica de manera supletoria el Código Civil.

¿Qué ocurre si el convenio arbitral no ha sido conocido o no pudo ser conocido por quien no lo redactó, usando una diligencia ordinaria? El Decreto Legislativo 1071 no sanciona con nulidad el convenio arbitral.

Este decreto legislativo, como la Ley de Arbitraje derogada, dice que las CGC "serán exigibles" siempre que hayan sido conocidas o hayan sido conocibles por la contraparte usando la diligencia ordinaria. Esto nos lleva a un remedio distinto: la "inexigibilidad".

En efecto, el convenio arbitral no es nulo, pero debe entenderse que el sometimiento al arbitraje rige para el predisponente y que no hay sometimiento para quien no lo redactó, de tal manera que este último, si quiere, puede decidir arbitrar.

El artículo 11 de la Ley de Arbitraje derogada era bastante claro cuando señalaba:

Si se estableciera que el convenio arbitral no fue conocido o conocible por la contraparte al momento de la celebración del contrato, el estipulante del convenio arbitral no podrá exigir su aplicación, salvo que posteriormente su contraparte lo acepte expresamente y por escrito. Empero, la contraparte sí podrá exigir la aplicación de dicho convenio arbitral, así este no hubiera sido inicialmente conocido o conocible. 
El Decreto Legislativo 1071 no contiene una norma similar; no obstante, consideramos que el señalar: "serán exigibles solo si", nos lleva a la misma solución del artículo 11 de la Ley de Arbitraje antes citado.

\section{La modificación del convenio arbitral}

Si tenemos en cuenta que el convenio arbitral es un acuerdo (un negocio jurídico al cual se le aplica la disciplina general de los contratos), entonces, como tal, puede ser modificado o extinguido en cualquier momento por un acuerdo posterior (Castro Zapata 2008: 60). ${ }^{44}$ Para modificar el convenio arbitral, las partes pueden optar por celebrar uno nuevo (negocio de segundo grado) o incluir las modificaciones en el acta de instalación. En este sentido, Castro Zapata señala: "La pregunta que surge y es materia de análisis en el presente ensayo es si resulta posible que el contenido del acta de instalación debe primar sobre lo pactado en el convenio arbitral, considerando que el acta de instalación nace en virtud del convenio arbitral". Más adelante responde: "la respuesta afirmativa se impone" (2008: 62). ${ }^{45}$

Cuando la modificación se realiza mediante un acuerdo de voluntades expresado en la audiencia de instalación (y recogido en el acta), debe quedar claro que quienes manifiestan la voluntad de modificar cuenten con poder suficiente para celebrar convenios arbitrales o, en caso de excederse en los límites de las facultades que se les hubiere conferido, que posteriormente el acto jurídico modificatorio sea ratificado por el o los representados.

En principio, debe considerarse que la modificación que consta en el acta de instalación sólo resulta de aplicación para el proceso arbitral objeto de la instalación. Así, si, por ejemplo, el convenio arbitral establece un plazo determinado para que el tribunal arbitral emita el laudo y en el acta de instalación se decide no someterse a dicho plazo, esta modificación solo alcanzará al proceso arbitral respecto al que se produce la instalación, de tal manera que si se produjera una nueva y distinta controversia se aplicará, en principio, el plazo fijado en el convenio arbitral original.

44 En el mismo sentido: Soto Coaguila (2011: 185).

45 En el mismo sentido: Soto Coaguila (2011: 186). 


\subsection{La forma para la modificación del convenio arbitral}

Como hemos visto, el convenio arbitral es, pues, un acuerdo dotado de autonomía e individualidad respecto al contrato; en ese sentido, la forma exigida para la modificación de este no se extiende a la modificación del convenio arbitral. En efecto, teniendo en cuenta que el convenio arbitral bajo la forma de cláusula es una "cláusula autosuficiente", sus requisitos de eficacia y validez son autónomos respecto a aquellos requeridos para el contrato.

El artículo 1413 del Código Civil establece: “Las modificaciones del contrato original deben efectuarse en la forma prescrita para ese contrato".

Se definen como de segundo grado aquellos negocios jurídicos que preparan, integran, modifican, ratifican o resuelven un negocio precedente, llamado de primer grado. En tal sentido, el contrato modificativo es un negocio jurídico de segundo grado, por lo que se les extienden a tales negocios las prescripciones de forma previstas para los actos de primer grado. Siendo así, para la modificación de un contrato con forma ad solemnitatem, la modificación debe efectuarse con la misma forma.

En cambio, si bajo la forma de cláusula existe en dicho contrato un convenio arbitral, para la modificación de este bastará tener en cuenta lo dispuesto en el artículo 13 del Decreto Legislativo 1071. Así por ejemplo, si el contrato es por escritura pública, bajo sanción de nulidad, la modificación del convenio arbitral podría hacerse, por ejemplo, por documento privado.

La imposición de la forma puede derivar - además de la ley - de la autonomía privada, a través de un pacto sobre la forma; así, las partes pueden convenir adoptar una determinada forma para la futura (y eventual) modificación del contrato. En efecto, el artículo 1411 del Código Civil establece: "Se presume que la forma que las partes convienen adoptar anticipadamente y por escrito es requisito indispensable para la validez del acto, bajo sanción de nulidad".

Salvo acuerdo distinto, ${ }^{46}$ la forma convenida se revela sobre el plano sustancial. En tal sentido, el contrato modificativo que no revista la forma prescrita convencionalmente, será nulo.

46 El pacto sobre la forma podría ser, en realidad, un pacto sobre la prueba, es decir, limitativo de los medios de prueba (Roppo 2001: 247). 
Si las partes convienen, en un contrato, que la modificación de este debe ser realizada por escrito, ${ }^{47} i$ la forma prescrita convencionalmente alcanza al convenio arbitral? Teniendo en cuenta que este convenio es un acuerdo dotado de autonomía e individualidad respecto al contrato, debe entenderse que este pacto sobre la forma no comprende al convenio arbitral, respecto del cual bastará considerar lo dispuesto en el artículo 13 del Decreto Legislativo 1071. Así por ejemplo, teniendo en cuenta el numeral 3 del artículo 13 del Decreto Legislativo 1071, podría darse una modificación a través de un comportamiento concluyente de los interesados (per facta concludentia), el que, en estricto, no supone la forma escrita. ${ }^{48}$

\section{Bibliografía}

Alpa, Guido (2004). Derecho del consumidor. Lima: Gaceta Jurídica.

Arias Schreiber Pezet, Max (1986). Exégesis. Tomo I. Con la colaboración de Carlos Cárdenas Quirós, Ángela Arias Schreiber Montero y Elvira Martínez Coco. Lima: Librería Studium.

Arrarte Arisnabarreta y Carlos Paniagua Guevara (2007). “Apuntes sobre el arbitraje administrativo y la materia arbitrable respecto de adicionales de obra". Revista Peruana de Arbitraje 4. Lima.

Benito Llopis-Llombart, Marco de (2010). El convenio arbitral. Su eficacia obligatoria. Madrid: Civitas/ Thomson Reuters.

Bennett, Steven (2002). Arbitration: Essential concepts. Nueva York: ALM Publishing.

Bernardes de Mello, Marcos (1986). Teoria do fato jurídico. 2. a edición. São Paulo.

Bianca, Massimo (1998). Diritto civile. 3. Il Contratto. Milán: Giuffrè.

Bullard González, Alfredo (2011). “Art. 14.- Extensión del convenio arbitral", en Comentarios a la ley peruana de arbitraje. Tomo I. Lima: Instituto Peruano de Arbitraje.

47 Así por ejemplo: “EI contrato sólo podrá ser sujeto a modificaciones mediante el acuerdo previo y por escrito de las partes".

48 Aunque no se presentarán problemas, pues el Decreto Legislativo 1071 utiliza la formula: "Se entenderá que el convenio arbitral consta por escrito". 
Caivano, Roque (2008). Arbitraje. 2. ${ }^{\text {a }}$ edición. Buenos Aires: Ad-Hoc.

Campos Medina, Alexander (2006). "La arbitrabilidad del enriquecimiento sin causa. A propósito de los contratos administrativos". Revista Peruana de Arbitraje 3. Lima.

Cantuarias Salaverry, Fernando (2007). Arbitraje comercial y de las inversiones. Lima: UPC.

Capobianco, Ernesto (2006). "La determinazione del regolamento", en Trattato del contratto. II regolamento. Milán: Giuffrè.

Caramaschi, Chiara (2007). "La clausola compromissoria". Il Civilista 1.

Cárdenas Quirós, Carlos (2000). “Las cláusulas generales de contratación y el control de las cláusulas abusivas", en Contrato \& Mercado. Lima: Gaceta Jurídica.

Cárdenas Quirós, Carlos (1985). “Exposición de motivos y comentarios. Cláusula compromisoria y compromiso arbitral", en Revoredo, Delia (comp.). Código Civil. Volumen VI. Lima: Okura.

Carleo, Roberto (1998). Le vicende soggettive della clausola compromissoria. Turín: Giappichelli.

Castillo Freyre, Mario y Ricardo Vásquez Kunze (2006). “El dominio contractual en el arbitraje". Ius et Veritas 32. Lima.

Castro Zapata, Laura (2008). "El convenio arbitral vs. el acta de instalación (o en qué ocasiones puede modificarse lo pactado en el convenio arbitral), en Arbitraje. Ponencias del Congreso Internacional de Arbitraje 2007. Volumen 6, segunda parte. Lima. Palestra.

Cintioli, Fabio (2003). Il contratto in generale. Problema attuali ed orientamenti di giurisprudenza. Volumen 1. Milán: Giuffrè.

Diener, María Cristina (2002). Il contratto in generale. Milán: Giuffrè.

Díez-Picazo y Ponce de León, Luis (2004). “Forma y contenido del convenio arbitral", en Comentarios a la nueva Ley de Arbitraje 60/2003, de 23 de diciembre. Navarra: Aranzadi.

Díez-Picazo, Luis (1986). Fundamentos del derecho civil patrimonial. Volumen 1. 2. a edición. Madrid: Tecnos.

Espinoza Espinoza, Juan (2003). “Las cláusulas vejatorias en los contratos estipulados unilateralmente", en Estudios sobre el contrato en general. Por los sesenta años del Código Civil Italiano (1942-2002). Lima: Ara. 
Falen Incháustegui, Óscar (2009). “El arbitraje obligatorio en el Estado”. Jus. Gestión Pública. Lima: Grijley.

Fernández Cruz, Gastón (2003). “Introducción al estudio de la interpretación en el Código Civil peruano", en Estudios sobre el contrato en general. Por los sesenta años del Código Civil italiano (1942-2002). Lima: Ara.

González de Cossío, Francisco (2008). "La nueva forma del acuerdo arbitral: otra victoria del consensualismo", en Arbitraje comercial y arbitraje de inversión. El arbitraje en el Perú y el mundo. Tomo I. Lima: Ediciones Magna.

Kundmüller Caminiti, Franz (1999). “Obligatoriedad del arbitraje y otros temas de gestión de conflictos en la Ley de Contrataciones y Adquisiciones del Estado y su reglamento". Themis 39. Lima.

La China, Sergio (2007). L'arbitrato. Il sistema e l'esperienza. 3. a edición. Milán: Giuffré.

La Puente y Lavalle, Manuel de (1991). “El contrato en general. Comentarios a la sección primera del libro VII del Código Civil", en Biblioteca Para Leer el Código Civil. Volumen XI, primera parte. Tomo III. Lima: Pontificia Universidad Católica del Perú, Fondo Editorial.

Latorre Boza, Derik (2008). "El arbitraje en la contratación pública”, en Ponencias del Congreso Internacional de Arbitraje 2007. Primera parte. Biblioteca de Arbitraje. Volumen 5. Lima: Palestra.

Lohmann Luca de Tena, Guillermo (1987). "El arbitraje”, en Para Leer el Código Civil. Volumen 5. Lima: Pontificia Universidad Católica del Perú, Fondo Editorial.

Lorca Navarrete, Antonio María (2002). “Algunas propuestas acerca de la naturaleza jurídica del arbitraje". Advocatus 7. Lima.

Marques Lima, Claudia (2002). Contratos no Código de Defesa do Consumidor. O novo regime das relacoes contratuais. $4^{\text {a }}$ edición. Sao Paulo: Editora Revista dos Tribunais.

Matheus López, Carlos Alberto (2005). "Introducción al convenio arbitral". Actualidad Jurídica 142. Lima: Gaceta Jurídica.

Miquel González, José María (2003). “Algunos aspectos del control de contenido de las condiciones generales en la Ley española de 1998", en separata del curso Derecho de Consumo y Derecho de Contratos. Santander: Universidad Internacional Menéndez Pelayo. 
Orestano, Andrea (2006). "Schemi alternativi", en Trattato del contratto. Tomo I. Formazione. Milán: Giuffrè.

Oricchio, Antonio (2001). Tutela del consumatore e servizi pubblici. Milán: Giuffrè.

Paladini, Mauro (1992). "Preliminare unilaterale, opzione, opzione di preliminare bilaterale", en Il contratto preliminare. Milán: Giuffrè.

Perales Viscosillas, Pilar (2007). “¿Forma 'escrita' del convenio arbitral?: nuevas disposiciones de la CNUDMI". Athina 3. Lima.

Roppo, Vincenzo (2001). "Il contratto", en Trattato di diritto privato. A cura di Giovanni Iudica y Paolo Zatti. Milán: Giuffrè.

Sacco, Rodolfo y Giorgio de Nova (1996). Il contratto. Tomo II. Turín: UTET.

Soto Coaguila, Carlos A. (2011). "Art. 13.- Contenido y forma del convenio arbitral", en Comentarios a la ley peruana de arbitraje. Tomo I. Lima: Instituto Peruano de Arbitraje.

Vidal Ramírez, Fernando (2005). El acto jurídico. Lima: Gaceta Jurídica.

Vidal Ramírez, Fernando (2003). "El convenio arbitral". Derecho PUC 56. Lima: Facultad de Derecho de la Pontificia Universidad Católica del Perú.

Wong Abad, Julio Martín (2008). "Presupuestos adicionales de obra, enriquecimiento sin causa y cláusula arbitral en los contratos administrativos. A propósito de una discusión entre (algunos) jueces y (algunos) árbitros". Jus. Jurisprudencia 9. Lima. 